\title{
Relationship Between Organizational Culture and Work Satisfaction With Commitment to Organization
}

(Study On The Employees Of Tous Les Jours Bakery)

\author{
Herman $\left.^{*}\right)$ \\ ${ }^{*}$ Universitas Pakuan, Bogor, Indonesia \\ Corresponding Author: herman_fhz@yahoo.co.id
}

\begin{abstract}
The purpose of this study is to determine the existence of a relationship between organizational culture and job satisfaction with the commitment to the organization (Studies On Employees Tous Les Jours Bakery).Population in this research is total employee of Tous Les Jours Bakery counted 364 people, while that will be used as sample of research is 200 employee of Kitchen Staff . Based on Slovin formula 133 people are taken as samples. The research instrument is questionnaire. The obtained data is then processed by using correlation analysis techniques with the assistance of SPSS (Statistical Package for Social Science) software. The results showed that: First, the organizational culture on organizational commitment has a significant relationship and has a contribution of $11.3 \%$. Second, job satisfaction and commitment to the organization has a very significant relationship and has a contribution of $21.7 \%$. Eventually, both organizational culture and job satisfaction simultaneusly have a very significant relationship and have contributed $25.7 \%$, the remaining $74.3 \%$ is determined by other unexamined variables.
\end{abstract}

Keywords: Organizational Culture, Job Satisfaction, Commitment to the Organization.

\section{INTRODUCTION}

One of the important assets of the organization is human resources (HR) which can drive other resources. Human resources affects the efficiency and effectiveness of the organization. This is what makes the fast food business entrepreneurs aware of the value of employee investment as a human resource. Now, it is getting difficult to obtain skilled and capable workforce in addition to maintaining existing ones. They should be prioritized in finding, hiring, motivating, training, developing to adapt to the fast food culture and the desired performance can be achieved, and quality employees can be retained.

Employee turnover is a frequent phenomenon in the fast food industry. Turnover can be interpreted as the movement of labor out of the organization. Turnover leads to the ultimate reality facing an organization in terms of the number of employees leaving the organization at a certain period while turnover intentions refers to individual evaluation results on the continuation of relationships with organizations that have not yet been realized in the exact course of action leaving the organization.

Employee turnover also occurs in one of the companies in the fast food industry, Tous Les Jours Bakery. Established in August 2011, Tous Les Jours Bakery is one of CJ Group Indonesia's food service divisions which currently has around 300 employees.
Of these, $40 \%$ are outsourced, while $60 \%$ are directly hired and selected by Tous Les Jours Bakery management, and then referred to as permanent employees.

The cause of the employees turnover is the decrease of the organizational commitment from employees. That increased commitment is associated with increased productivity and lower turnover. Commitment is an important aspect of the philosophy of human resources management (HRM). Understanding commitment itself develops no longer merely in the form of willingness of employees to stay in the organization in the long term. More than that, employees are willing to give the best and even willing to be loyal to the organization.

The positive organizational culture creates a commitment to organization. The organizational culture is a mutual agreement of the members within the organization or company so as to facilitate the birth of a wider agreement for the benefit of individuals. The virtue of organizational culture is the control and direction in shaping the attitudes and behaviors of people who engage themselves in an organization's activities. Organizational culture affects productivity, performance, commitment, confidence and ethical behavior. In addition there are variables derived from the individual self itself (internal) that has an important role in increasing commitment to the organization that is job satisfaction. 
Job satisfaction is as a general attitude of the individual to his work in this case is the employee. Employees can assess how satisfied or dissatisfied he / she with his job. Job satisfaction can also be described as having a positive attitude toward work in a person. The evidence of research on job satisfaction can be seen from several categories such as leadership, psychological needs, rewards or endeavors, ideological management and values, as well as factors of work design and workload. Job satisfaction can have a substantial influence on organizational commitment to the fast food industry. Fast-food industry employees with a higher level of job satisfaction are more committed than employees with low job satisfaction.

\section{Formulation of the problem}

Some problems that cause low commitment to the organization mentioned above in this discussion can be formulated as follows: 1. Is there a relationship between organizational culture and commitment to the organization? 2. jApakah there is a relationship between employee job satisfaction with commitment to the organization? 3. Is there a relationship between organizational culture and job satisfaction together with commitment to the organization?

\section{The Nature of Commitment to the Organization}

Allen and Meyer in Darmawan define commitment to the organization as a concept that has three dimensions, namely affective, normative, and continued commitment. Affective commitment is the degree to which an employee is emotionally bound, familiar and involved in the organization. Continue commitment is an assessment of the costs associated with leaving the organization. Normative commitment shows the degree to which a person is psychologically bound to be an employee of an organization based on feelings such as loyalty, affection, warmth, possessiveness, pride, pleasure, happiness, etc. At the same time, almost equal opinions about the definition of commitment to the organization proposed by Caldwell, Chatman and O'Rielly stating that commitment to the organization is a psychological bond between employees and organizations. This organizational commitment can be expressed in three separate bases of attachment, namely compliance, identification, and internalization. Compliance leads to instrumental attachment in the form of special rewards. Identification leads to stickiness based on the desire to join the organization

Meanwhile, Mowday states that work commitment is another term of organizational commitment. In his view, organizational commitment is an important behavioral dimension that can be used to assess employees' propensity to survive as members of an organization. ${ }^{2}$ Organizational commitment is a relatively strong identification and involvement of a person to the organization. Organizational commitment is the desire of members of the organization to maintain its membership in the organization and willing to strive for the achievement of organizational goals. A similar point was made by Newstorm and Davis explaining that organizational commitment, or employee allegiance reflects how far employees feel engaged and engaged with the organization so that employees are willing to remain active in the organization. It is a measure of the willingness of employees to remain within the organization and reflects employees' beliefs in the mission and goals of the organization, willingness to work hard to achieve goals, and have an intention to continue working within the organization. Strong commitment is usually owned by employees who have worked in the long term, they have experienced personal success in the organization. Committed employees will have a good attendance record, demonstrate compliance with organizational policies, and have low turnover rates.

Then Mathias and Jackson state that organizational commitment is the extent to which employees believe and accept the goals of the organization and have a desire to remain with the organization. This relates to the extent of employee involvement to contribute to the organization.

In addition, Kreitner and Kinicki explain that organizational commitment reflects the extent to which an individual identifies itself with the organization and is related to its goals. This is an important work attitude, because committed employees are expected to show willingness to work hard to achieve organizational goals and have a great desire to keep working within the organization.

\section{The Nature of Organizational Culture}

According to O'Reilly, Chatman and Caldwell, the organizational culture is a form of reference for the interaction of members of the organization and the form of reference of interaction with outsiders. The form of reference is the values, norms and rules as the basis for members to think and behave. Then the essence of organizational culture is a tool for interpreting and reacting objective conditions, and organizational culture can be a source of competitive advantage.

Meanwhile, Robbins says that organizational culture has a definition as dominant values supported by organizations or philosophies that guide organizational policies to employees and customers, or the way work is done in the workplace, or the basic assumptions and beliefs that exist among members of the organization.

The same opinion expressed by Schein. He explains that organizational culture consists of basic assumptions learned both as a result of solving problems arising in the process of adjustment to the environment, as well as the result of solving problems arising from within the organization, between the related organizational units with integration. Culture arises as a result of the joint study of members of the 
organization in order to survive. The legitimate basic assumptions are taught to new members as a proper way of observing, thinking and feeling in relation to those problems.

Then Sedarmayanti defines organizational culture as a commonly held belief, attitudes and values, which arise within the organization, further explained culture is the way we do things within an organization. Patterns of values, norms of beliefs, attitudes and assumptions may not be disclosed, but will shape the way people behave in doing things. Value refers to what is believed to be important about how employees and organizations behave. The norm is an unwritten rule of conduct. Organizational culture is a subjective aspect of what happens within the organization. This refers to abstractions, such as values and norms that cover all or part of a business.

\section{The Nature of Job Satisfaction}

Spector defines job satisfaction as an attitude that reflects how the individual's evaluative feelings about his work, both overall and from various aspects of his work. These feelings range from likes or satisfactions to their work or dislike or dissatisfaction with their work. "Furthermore, Howel and Dipboye defines job satisfaction as the overall result of the degree of the likes or dislikes of labor to various aspects of their work. In other words, job satisfaction reflects the attitude of the workforce to its work.

Meanwhile, according to Robbins, job satisfaction is a general attitude towards a person's job that shows the difference between the amount received by the worker and the amount they believe they should receive.

The same opinion expressed by Organ and Hamner who explained that job satisfaction is a person's attitude towards his job. It is a complex collection of beliefs and knowledge, emotions (feelings, sentiments, evaluations) and behavioral trends. A person with a high level of job satisfaction has a very positive attitude about his job, and conversely people who are not satisfied with their work will have a negative attitude towards the job.

\section{RESEARCH METHODS}

The method used in this research is to use the form of descriptive research with quantitative data analysis. Descriptive research is a form of research that focuses on actual problems or phenomena at the time the research is done then describes the facts about the problem investigated as it is accompanied by a rational and accurate interpretation. The data used is quantitative data derived from the results of the survey in the form of distributing questionnaires to the sample employee Kitchen Staff Tous Les Jours Bakery selected by stratified random sampling method. Before used the data is tested its validity with correlation method pearson and its reliability by using alpha cronbach method. Test requirements analysis performed with normality test, homogeneity test and data linearity test.

Hypothesis test is done by using correlation coefficient method as follows:

The relationship between organizational culture with commitment to organization, the test is done by simple correlation technique to see the strength of relationship between organizational culture variable $\left(\mathrm{X}_{1}\right)$ with commitment to organization $(\mathrm{Y})$.

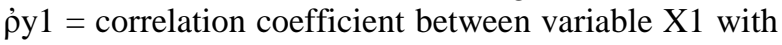
variable Y.

The relationship between job satisfaction with commitment to the organization, the test is done by simple correlation techniques to see the strength of the relationship between job satisfaction variables $\left(\mathrm{X}_{2}\right)$ with commitment to the organization $(\mathrm{Y})$.

$\dot{\rho} \mathrm{y}_{2}=$ correlation between variable $\mathrm{X}_{2}$ with variable $\mathrm{Y}$.

The relationship between organizational culture and job satisfaction together with commitment to the organization, the test is conducted by double correlation technique and Product Moment Corelation. To see the strength of the relationship between organizational culture variables $\left(\mathrm{X}_{1}\right)$ and job satisfaction variables $\left(\mathrm{X}_{2}\right)$ together with commitment to the $\operatorname{organization}(\mathrm{Y})$. $\dot{\rho}_{\cdot 1.2}=$ correlation between variables $X_{1}$ with $X_{2}$ together with variable $Y$

\section{RESULTS AND DISCUSSION}

\section{Validity test}

An item is declared valid if $r$ count $>r$ table. From the results of validity test with Pearson correlation using SPSS 16 obtained results:

1. For the variable commitment to the organization, from 40 question items obtained the number of valid items of 26 items.

2. For the organizational culture variable, from 40 question items obtained the number of valid items as much as 22 items.

3. For job satisfaction variable, from 40 question items obtained the number of valid items of 27 items.

\section{Reliability testing}

A variable is considered reliable if the value of alpha cronbach $\geq 0.7$. From result of reliability test with alpha cronbach method using SPSS 16 obtained by alpha cronbach value for commitment variable to organization 0,795 ; organizational culture 0.852 ; and job satisfaction variable 0,773 . Thus all variable items are declared reliable.

\section{Normality testing}

The data of a variable is normally distributed if the degree of significance of the Kolmogorov Smirnov One-Sample Test> 0.05. From the test results One-Sample Kolmogorov Smirnov obtained the degree of significance of the commitment variable to the organization 0.742 ; organizational culture 0,559 ; job satisfaction 0.444 . Thus all variable items are otherwise normally distributed. 


\section{Homogeneity Testing}

Homogeneity of data variance Commitment to Organization $(\mathrm{Y})$ over Organization Culture $\left(\mathrm{X}_{1}\right)$ is tested by using bartlett test. Based on the calculation results obtained value $\chi 2$ count $=8.35$, while $\chi 2$ table $=$ 126.57. The homogeneous data requirement is $\chi 2$ count $<\chi 2$ table, thus the Organizational Commitment (Y) data and Organization Culture $\left(\mathrm{X}_{1}\right)$ data come from populations having the same variance (homogeneous)

Homogeneity of data variance Commitment to Organization $(\mathrm{Y})$ on Job Satisfaction $\left(\mathrm{X}_{2}\right)$ tested by using bartlett test. Based on the calculation results obtained values $\chi 2$ count $=0.20$, while $\chi 2$ table $=$ 126.57. The homogeneous data requirement is $\chi 2$ count $<\chi 2$ table, thus the Organizational Commitment $(\mathrm{Y})$ and Job Satisfaction data (X2) data come from populations having the same (homogeneous) variance.

\section{Linearity Testing}

The free variable score is expressed linearly to the dependent variable if the linearity test results have a degree of significance $<0.05$. From result of linearity test by using SPSS 16 obtained degree of significance test of linearity of organizational culture variable with commitment to organization 0,001 ; and job satisfaction variable with commitment to organization 0,000 ; thus all the independent variable data are expressed linearly to the dependent variable.

\section{Hypothesis testing}

Relationship between Organizational Culture $\left(\mathrm{X}_{1}\right)$ and Commitment to Company (Y).

Formulation of the first hypothesis in this study is there is a positive relationship between organizational culture (X1) with commitment to the organization $(\mathrm{Y})$. After testing the requirements of analysis through normality test, homogeneity and linearity obtained the calculation of the functional relationship of the two organizational culture variables (X1) with commitment to the organization (Y) obtained the following results:

In accordance with the statistical hypothesis, the relationship between organizational culture with commitment to the organization by using product moment correlation coefficient obtained correlation coefficient ry ${ }_{\cdot 1}=0.336>$ rtabel $($ rtabel $=0,176$ at $\alpha=$ $0,05$ and rtabel $=0,230$ at $\alpha=0,01)$. The relationship is significant because $\mathrm{Sig}=0.001$ This value is identical with $\mathrm{p}$-value, where the $\mathrm{p}$-value is smaller than $\alpha(0.05)$. Thus $\mathrm{H}_{0}$ is rejected and $\mathrm{H}_{1}$ accepted, meaning there is a positive and significant relationship between organizational culture $\left(\mathrm{X}_{1}\right)$ with commitment to organization $(\mathrm{Y})$.

Contribution of organizational culture $\left(\mathrm{X}_{1}\right)$ with commitment to organization $(\mathrm{Y})$ is calculated based on coefficient of determination that is $r^{2}=$ $\left(\mathrm{ry}_{\cdot 1.2}\right)^{2}=0,113$. Means the organizational culture variables form a contribution of $11.3 \%$ of commitment to the organization $(\mathrm{Y})$.
Functional relationship between organizational culture with commitment to organization is calculated using regression analysis technique $\hat{\mathrm{Y}}=$ $54,338+0,448 X 1$. Significant test of regression equation obtained conclusion that Fcount $=12,853$ > Ftable (Ftabel $=3.07$ at $\alpha=0,05$ and Ftabel $=4,78$ at $\alpha$ $=0,01)$. This means that the regression equation is so significant that organizational culture variables can be used to predict commitment to the organization.

To test the hypothesis that there is a positive relationship between variables $\mathrm{X} 1$ with $\mathrm{Y}$ required test significance correlation coefficient that is with $\mathrm{t}$ test. Criteria for testing the significance of the correlation coefficient is if thitung $>$ ttable. From table 23 Coefficients obtained tcount $=3.585, \mathrm{Sig}=0,05$ and $\mathrm{N}$ -1 or $103-1=102$ obtained ttable $=1,659$. It turns out that the value of $t$ count $>$ ttable or 3,585>1,659, means organizational culture $\left(\mathrm{X}_{1}\right)$ is very significant to the commitment to the organization (Y).

Table1. Result of Calculation of Correlation Significance Test of Variables X1 and Y

\begin{tabular}{|c|c|c|c|c|c|}
\hline \multirow{2}{*}{$\begin{array}{c}\text { Coeficient } \\
\text { of } \\
\text { Corelation }\end{array}$} & \multirow{2}{*}{$\mathrm{dk}$} & $\mathrm{t}_{\text {hitung }}$ & \multicolumn{2}{|c|}{$\mathrm{t}_{\text {tabel }}$} & \multirow{2}{*}{ Coclusion } \\
\cline { 3 - 5 } & & 0,05 & 0,01 & \\
\hline 0,336 & 102 & $3,585^{* *}$ & 1,659 & 1,983 & $\begin{array}{c}\text { Very } \\
\text { significant }\end{array}$ \\
\hline
\end{tabular}

Relationship between Job Satisfaction $\left(\mathrm{X}_{2}\right)$ with Commitment to Company (Y).

Formulation of the second hypothesis in this study is there is a positive relationship between job satisfaction $\left(\mathrm{X}_{2}\right)$ with commitment to the organization (Y). After testing the requirements of analysis through normality test, homogeneity and linearity obtained the calculation of the functional relationship of the two job satisfaction variables $\left(\mathrm{X}_{2}\right)$ with commitment to the organization $(\mathrm{Y})$ obtained the following results:

In accordance with the statistical hypothesis, the relationship between job satisfaction with commitment to the organization by using the product moment correlation coefficient obtained ry.2 $=$ $0.466>$ ). The relationship is significant because $\mathrm{Sig}=$ 0,000 is identical to $p$-value, where $p$-value is less than $\alpha(0,05)$. Thus $\mathrm{H}_{0}$ rejected and $\mathrm{H}_{1}$ accepted, means there is a positive and significant relationship between job satisfaction $\left(\mathrm{X}_{2}\right)$ with commitment to the organization $(\mathrm{Y})$.

Contribution of job satisfaction $\left(\mathrm{X}_{2}\right)$ with commitment to organization (Y) is calculated based on coefficient of determination that is $\mathrm{r}^{2}=\left(\mathrm{ry}_{\cdot 2}\right)^{2}=0,217$. Means the variable of job satisfaction form a contribution of $21.7 \%$ of commitment to the organization $(\mathrm{Y})$.

The functional relationship between job satisfaction and commitment to the organization was calculated using regression analysis technique 
$\hat{Y}=43,852+0,487 X_{2}$. Significant test of regression equation obtained conclusion that Fcount $=28,046>$ Ftable (Ftabel $=3.07$ at $\alpha=0,05$ and Ftabel $=4,78$ at $\alpha$ $=0,01)$. This means that the regression equation is so significant that job satisfaction variables can be used to predict commitment to the organization.

To test the hypothesis that there is a positive relationship between variables $\mathrm{X} 2$ with $\mathrm{Y}$ required test significance correlation coefficient that is with test. Criteria for testing the significance of the correlation coefficient is if thitung $>$ ttable. From Table 24 Coefficients obtained tcount $=5.296, \mathrm{Sig}=0,05$ and $\mathrm{N}$ - 1 or $103-1=102$ obtained ttable $=1,659$. It turns out that the value of $t$ count $>$ ttable or 5.296> 1.659, means job satisfaction $\left(\mathrm{X}_{2}\right)$ is very significant to the commitment to the organization $(\mathrm{Y})$.

Table 2. Result of Calculation of Correlation Significance Test of Variables X2 and Y

\begin{tabular}{|c|c|c|c|c|c|}
\hline \multirow{2}{*}{\begin{tabular}{c} 
Coeficient $\begin{array}{c}\text { of } \\
\text { Corelation }\end{array}$ \\
\cline { 4 - 5 }
\end{tabular}} & $\mathrm{dk}$ & $\mathrm{t}_{\text {hitung }}$ & $\begin{array}{c}\alpha= \\
0,05\end{array}$ & $\begin{array}{c}\alpha= \\
0,01\end{array}$ & Kesimpulan \\
\hline 0,466 & 102 & $5,296^{* *}$ & 1,659 & 1,983 & $\begin{array}{c}\text { Sangat } \\
\text { Signifikan }\end{array}$ \\
\hline
\end{tabular}

Relationship between Organizational Culture $\left(\mathrm{X}_{1}\right)$ and Job Satisfaction $\left(\mathrm{X}_{2}\right)$ together with Commitment to Organization (Y).

The third hypothesis tested is the positive relationship of Organizational Culture $\left(\mathrm{X}_{1}\right)$ and Job Satisfaction $\left(\mathrm{X}_{2}\right)$ together with Commitment to Organization (Y).

In accordance with the statistical hypothesis, the relationship between Organizational Culture $\left(\mathrm{X}_{1}\right)$ and Job Satisfaction $\left(\mathrm{X}_{2}\right)$ together with Commitment Against Organization ( $\mathrm{Y}$ ) by using product moment correlation coefficient ry $_{1.2}=0,507>$ rtabel $($ rtabel $=$ 0,176 at $\alpha=0.05$ and rtable $=0.230$ at $\alpha=0.01$ ). The relationship is significant because $\mathrm{Sig}=0,000$ is identical to $\mathrm{p}$-value, where $\mathrm{p}$-value is less than $\alpha(0,05)$. Thus $\mathrm{H}_{0}$ rejected and $\mathrm{H}_{1}$ accepted, means there is a positive and significant relationship between Organizational Culture $\left(\mathrm{X}_{1}\right)$ and Job Satisfaction $\left(\mathrm{X}_{2}\right)$ together with Commitment to Organization (Y).

The contribution of Organizational Culture $\left(\mathrm{X}_{1}\right)$ and Job Satisfaction $\left(\mathrm{X}_{2}\right)$ together with Commitment to Organization (Y) is calculated based on coefficient of determination that is $r_{2}=(r y \cdot 1.2)^{2}=$ 0,257 . Means variable Organizational Culture $\left(\mathrm{X}_{1}\right)$ and Job Satisfaction $\left(\mathrm{X}_{2}\right)$ form a contribution of $25.7 \%$ of Commitment Against Organization (Y).

The Functional Relationship between Organizational Culture $\left(\mathrm{X}_{1}\right)$ and Job Satisfaction $\left(\mathrm{X}_{2}\right)$ together with Commitment to Organization (Y) is calculated using regression analysis technique $\hat{\mathrm{Y}}=50,004-0,622 \mathrm{X}_{1}+0,928 \mathrm{X}_{2}$. Significant test of regression equation obtained by conclusion that Fcount
$=17,312>$ Ftabel $($ Ftabel $=3.07$ at $\alpha=0,05$ and Ftabel $=4,78$ at $\alpha=0,01)$. This means that the regression equation is so significant that the Organizational Culture $\left(\mathrm{X}_{1}\right)$ and Job Satisfaction $\left(\mathrm{X}_{2}\right)$ variables can be used to predict the Commitment to the Organization.

To test the hypothesis that there is a positive relationship between variables $\mathrm{X} 1$ and $\mathrm{X} 2$ together with Y required correlation coefficient significance test that is with test F. Criteria testing significance of correlation coefficient is if Fcount> Ftabel. After tested the following results are obtained:

Table 3. Result of Calculation of Correlation Significance Test of Variables $\mathrm{X}_{1}$ and $\mathrm{X}_{2}$ together with the $\mathrm{Y}$ variable

\begin{tabular}{|c|c|c|c|c|}
\hline \multirow{2}{*}{$\begin{array}{c}\text { Coeficient } \\
\text { of } \\
\text { Corelation }\end{array}$} & $F_{\text {hitung }}$ & $\alpha=0,05$ & $\alpha=0,01$ & Kesimpulan \\
\cline { 3 - 4 } & $17,312^{* *}$ & 3,07 & 4,78 & $\begin{array}{c}\text { Sangat } \\
\text { Signifikan }\end{array}$ \\
\hline 0,507 & & $\mathrm{~F}_{\text {tabel }}$ & \\
\hline
\end{tabular}

\section{CONCLUSION}

Apart from the weaknesses and shortcomings of this research, both in terms of methodology and in terms of objects, several results can be summarized as follows:

1. Organizational culture has a positive relationship with the commitment of employees to the organization and the strength of weakness of the relationships. This means that the commitment to the organization of Tous Les Jours Bakery employees is largely determined by the Organizational Culture. Good organizational culture will lead to the employees commitment to the organization and vice versa. If the organizational culture is unfavorable then the employee's commitment to the organization is also low.

2. Job satisfaction has a positive relationship with employees' commitment to the organization and the strength of the relationship is. This means that the commitment to the organization of Employee Tous Les Jours Bakery is determined by job satisfaction. High job satisfaction will lead to high employee commitment to the organization and vice versa if job satisfaction is low then the employee's commitment to the organization is also low.

3. Organizational culture and job satisfaction together have a positive relationship with commitment to the company and the strength of the relationship is. So if the organizational culture and job satisfaction are automatically upgraded the organization's commitment to Tous Les Jours Bakery employees will increase and vice versa if if organizational culture and job satisfaction is low then commitment 
to organization at Employee Tous Les Jours Bakery is also low.

Based on the conclusions and implications of the study, some suggestions can be put forward as follows:

1. Recommendation for increasing commitment to the organization

Employees within the company are the main factors in the implementation to achieve company goals. Therefore, employees within the company should be able to increase commitment to the organization, because with a commitment to a high organization will achieve corporate objectives. The things that can be done in increasing commitment to the organization are: Companies must be able to bond with employees both procedurally and socially. The organization must be able to appreciate the work done by its employees so that employees will feel comfortable to work in the organization and will not leave the organization. Organizations must be able to raise employees' awareness that commitment to the organization is the right thing to do, because the impact of commitment to the organization will facilitate the achievement of an objective that has been planned by the organization.

2. Recommendations to improve organizational culture

The organization is able to make new innovations and develop the risk-taking process so that all work activities are at a very low risk. The organization must be able to create stability and security to its employees, so that employees feel secure or get assurance of safety and security in the work so that employees can complete the organization has been established in accordance with the applicable SOP. Training should be given to the employees or input from the organization on the importance of respecting the idea or work of fellow co-workers, because they are linked in achieving the goals of the organization. Organizations are able to plan, organize, mobilize and supervise employees aimed at achieving predetermined results orientation. Organizations are able to create team orientation and collaboration among employees in order to make it easier to equate common goals. Organizations are able to grow employee aggresiveness and increase positive competition in terms of work.

3. Suggestions to improve job satisfaction

The organization shall be consistent in the appropriateness of the salary amount, the date of receipt of salary in accordance with the provisions set by the organization.

Organizations provide opportunities in the form of promotion in the form of career ladder improvement openly on every employee who excel in terms of work.

Organizations are able to establish interaction between employees with their superiors to create a harmonious atmosphere.
The organization provides facilities in the form of facilities and infrastructure to support the work. Organizations and employees must be able to comply with the existing rules of the organization.

\section{REFERENCES}

Allen, NJ \& Meyer JP. 1990. The Measurement and Attecedent of Affective, Continuance and Normative Commitment to the Organization. Journal Of Occupational Psychologi: 1990

Balay. R \& Ipek. C. 2010. Teachers Perception Of Organizational Culture And Organizational Commitment In Turkish Primary Schools". Journal of World of Turks. Vol.2, No.1.

Caldwell, et.al. 1992, Buliding Organizational Commitment: A Multifirm Study,Journal of Occupational Psychology, The British Psychological Society.

Dipboye, R. S., Smith, C. S., \& Howell, W. C. 1994. Understanding industrial and organizational psychology: An integrated approach, Orlando: Harcourt, Brace \& Co, International Edition, 1994

Feinstein. A.H. 2002, A Study Relationship Between Job Satisfaction And Organizational Commitment Among Restaurant Employees"

Hana Chrysanti Widyastuti. 2010. Hubungan Antara Budaya Organisasi Dengan Komitmen Organisasi Pada Perawat Rumah Sakit Panti Wilasa Citarum Semarang. Tesis Pascasarjana Universitas Diponegoro.

Kreitner. R \& Kinicki. A. 2007. Organizational Behaviour"(6th ed). China : Mc Graw Hill Companies.

Miner, J.B. 1992. Industrial-Organizational Psychology United States of America: McGrawHill.

Mowday, R.T, Porter, L.W dan Steers R.M. 2002, Employee Organization Lingkages: The Psychology of Commitment, Absenteeism and Turnover London: Academic Press Inc.

Organ, Dennis W. dan W. Clay Hammer. 1982. Organizational Behavior, An Applied Physhological Approach, Texas:Business Publications.

Prima Ariestonandri. 2006. Marketing Research for Beginer Yogyakarta

Robbins, P Stephen. 2001. Prinsip-Prinsip Perilaku Organisasi, edisi kelima, dialih bahasa, Halida. Jakarta : Erlangga.

Robert L. Mathis \& John H. Jackson. 2006. Human Resources Management Edisi Sepuluh Jakarta : Salemba Empat.

Schein, E.H. 1992. Organizational Culture and Leadership San Fransisco : Jossey Bass

Sedarmayanti. 2007., Sumber Daya Manusia dan Produktivitas Kerja, Bandung : Mandar Maju. 
Siswanto \& Sucipto. A. 2008. Teori \& Perilaku Organisasi", Sebuah Tinjauan Integratif, Malang : UIN Malang Press.

Sopiah. 2008. Perilaku Organisasi" Yogyakarta : Andi.

Steers, R.M and Porter, L.W. 1991, Motivation and Work Behavior New York:McGraw Hill Book Co

Spector, Paul. 2000. Industrial and Organizational Psychology: Research anda Practice New York: John Wiley \& Sons.

Sugiyono. 2007. Metode Penelitian Bisnis Bandung : Alfabeta.

Veithzal Rivai. 2004. Manajemen Sumber Daya Manusia Untuk Perusahaan : Dari Teori Ke Praktik. Jakarta : Raja Grafindo Persada.

Wirawan, 2007. Budaya dan Iklim Organisasi. Jakarta : Salemba Empat

Wu A, Chow CW, Mc. Kinnon JL \& Harisson. GL. 2001., Organizational Cultural: Association With Commitment, Job Satisfaction, Propensity to Remain \& Information Sharing in Taiwan. 